\title{
Harmonic Response Analysis of Strut Fin on Planar Motion Mechanism
}

\author{
Kusnindar Priohutomo ${ }^{\mathrm{a} *}$, Danang Ariyanto ${ }^{\mathrm{b}}$ \\ ${ }^{\mathrm{a}}$ Indonesian Hydrodynamics Laboratory, Agency for the Assessment and Application of Technology (BPPT), Indonesian. \\ Email:kusnindar.priohutomo@gmail.com \\ ${ }^{b}$ Indonesian Hydrodynamics Laboratory, Agency for The Assessment and Application of Technology (BPPT), Indonesian. \\ Email:kusnindar.priohutomo@gmail.com
}

\begin{abstract}
In a material selection, the design that will be used is one important step because by selecting the right material with the appropriate material properties, the harmonic response value of the structure can be seen. By knowing the value of harmonic response in a structure, at the time of testing, damage to the structure can be avoided. In this study, the material used for Fin Planar Motion Mechanism (PMM) is Stainless Steel 304 (SS 304). To calculate the harmonic response, the SPSS (square root) method is used. From the research results, in the range $1-100 \mathrm{~Hz}$ the displacement value is still below the limit with a maximum value of $2.50 \mathrm{E}-12 \mathrm{~mm}$ and a maximum stress value of $2.95 \mathrm{E}-05 \mathrm{~Pa}$.
\end{abstract}

Keywords: Finite element method; harmonic response; natural frequency; strut fin; planar motion mechanism

\section{Introduction}

Strut Fin on Planar Motion Mechanism (PMM) is used as a ship model holder and as a load cell stand that will measure the forces acting during the test. PMM was first designed by Gertler and Goodman et al. [1] installed on David Taylor Model Basin (DTMB) in 1960, which later made improvement in measurement captive model test. From PMM, it can be produced pure sway ship motion, pure yaw ship motion, and combination sway and yaw ship. A load cell is used to measure forces resulting from strut fin movement which is in front and behind the PMM in oscillation motion (See Fig.1).

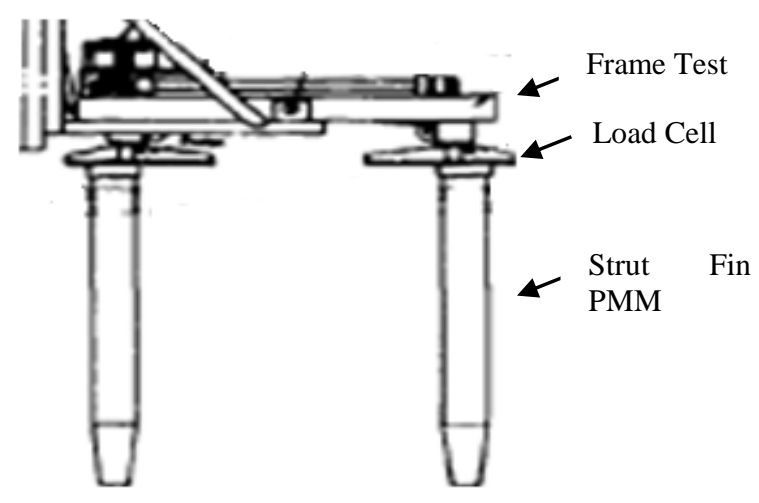

Figure 1. Planar Motion Mechanism in TT

${ }^{\star}$ Corresponding author. Tel.: +62-315948060

Jl. Hidrodinamika, Kompleks ITS, Sukolilo

Surabaya, Indonesia, 60112
The PMM equipment is used on the carriage Towing Tank (TT) that belongs BTH-BPPT. With this combination of tests, needed Strut Fin PMM design is strong and lightweight so that the frequency produced by the motor at the time of testing does not affect the reading of the load cell on Strut Fin PMM.

In the design stage of a structure, the natural frequency is one of the points that must be considered. Because by knowing the natural frequency, it can be used to calculate the value of the failure rate and the level of damage from a structure. Many studies have been conducted to calculate the value of natural frequency, including research on reference [2]. This study discusses the effect of crack produced using a natural frequency approach to structural materials that have a beam type. In this study, the natural frequency analysis uses the help of ANSYS FEM software. The results of this study were to determine the location of cracks in structures with crack depths around 1-3 mm. The effects of natural crack frequency are analyzed as health structures using mode 1 to mode 4.

The next study in [3] discusses experimental modal analysis (EMA) to analyze the crack that occurs in the beam. Where natural frequency mode 1 used as a reference for detecting the occurrence of a crack in the structure. The intersection of the three contours provides information on the location of the crack and depth of the crack. The results of the case study show the ability and efficiency of the method developed. 
Another research in [4] discusses failure modes dan buckling loads of composite plate under uniformly distributed loading and deflection is investigated by using analytical and theoretical approaches. Conclusion in this research is that the composite plate carries out the theoritical and the FEM results and is found to be around $8-10 \%$ difference. The achieved deflection factor is 5.4 against 4.6 in FEM. However, the results of FEM show close agreement with theoritical results.

Another study in [5] discusses a relation which describes the influence of discontinuities on the dynamic response of prismatic cantilever beams. The relation providing the natural frequencies of weak-axis bending vibration modes of damaged beams was contrived by considering the continous model in a global approach, opposite to researches presented in the literature involving mainly models based on two segments linked by a rotational spring and focusing on the local effect of the discontinuity.

From some of the studies that have been mentioned, the authors conducted research on natural frequencies in Strut Fin PMM with various types of material used and analyzed using modal analysis method assisted by Finite Element Method software (FEM).

\section{Method}

The research method was developed to be able to calculate the natural frequency Strut Fin PMM where steps in the research method can be explained as follows:

\subsection{Material type}

The choice of material type is the first thing in predicting the natural frequency of a structure. In this study, the material chosen was Stainless Steel 304 (SS304). Stainless steel 304 (SS304) is one of the stainless steel that is often used in the design industry. Because SS304 has advantages such as having resistance to corrosion against a variety of good environmental conditions [6-9]. SS304 has chemical properties shown in Table 1 and material properties shown in Table 2.

Table 1. Chemical Properties

\begin{tabular}{cc}
\hline Properties & Composition \\
\hline $\mathrm{C}$ & 0.05 \\
\hline $\mathrm{Si}$ & $1.08-1.49$ \\
\hline $\mathrm{Mn}$ & 0.35 \\
\hline $\mathrm{P}$ & 0.038 \\
\hline $\mathrm{S}$ & 0.001 \\
\hline $\mathrm{Ni}$ & $8.5-10.6$ \\
\hline $\mathrm{Cr}$ & $18.65-21.20$ \\
\hline $\mathrm{Fe}$ & 66.4 \\
\hline
\end{tabular}

Table 2. Mechanical Properties

\begin{tabular}{lc}
\hline \multicolumn{2}{c}{ Properties } \\
\hline Density & $1.08-1.49$ \\
\hline Tensile Strength (Yield) & $215 \mathrm{MPa}$ \\
\hline Tensile Strength (Ultimate) & $505 \mathrm{MPa}$ \\
\hline Modulus of Elasticity & $193-200 \mathrm{GPa}$ \\
\hline Poisson Ratio & 0.29 \\
\hline Shear Modulus & $86 \mathrm{GPa}$ \\
\hline
\end{tabular}

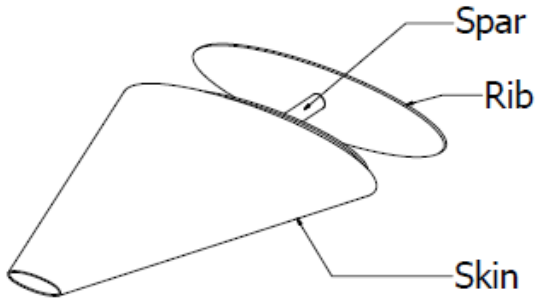

Figure 2. Design Strut Fin PMM

\subsection{Strut fin PMM design}

The components of the Strut Fin PMM compiler are components that are commonly used in structural design. Where consists of ribs arranged into 5 parts from the largest to the smallest. Rib Strut Fin PMM is made from SS304 material. Whereas for reinforcement is given an amplifier in the form of a spar that is connected from the largest rib to the smallest rib. The spar is mounted in the middle position of the rib. Spar is connected with Rib using the welding method so that it becomes the main structure Strut Fin PMM. Spar Strut Fin PMM is made of SS304 material. The skin has a thickness of $10 \mathrm{~mm}$ and is used to make the flow of fluid passing through it smooth during the test (See Fig. 2).

\subsection{Model Analysis}

The calculation method used to analyze the natural frequency of Strut Fin PMM is Modal Analysis. Modal analysis is used to analyze natural frequencies because using the method modal analysis can find out natural mode (change the shape of a structure), calculate natural frequency, calculate the response of each mode, calculate the response in each mode if the system is loaded. The natural frequency of a system depends on the stiffness and mass of a structure, does not depend on the load received by the system. The results of the natural frequency are in the form of structure. Based on the results of natural frequency, vibration analysis can be calculated to avoid or reduce the excitation effect of the largest frequency. The kinematic equation of the free vibration on the structure is a simple harmonic vibration, which means that the displacement meets the sine.

$$
x(t)=c_{1} \cos (\omega t)+c_{2} \sin (\omega t)
$$

Equation 1 can be written

$$
x(t)=A \cos (\omega t-\varphi)
$$

where:

$$
\omega=\sqrt{\frac{k}{m}}, A=\sqrt{C 1^{2}+C 2^{2}}, \tan \varphi=\frac{C 2}{C 1}
$$

$$
\begin{aligned}
\omega & =\text { angular frequency } \\
A & =\text { amplitude } \\
\varphi & =\text { phase }
\end{aligned}
$$




\subsection{Harmonic response analysis}

Harmonic response analysis using finite element models SPSS (square root method), harmonic response analysis based on Response Spectrum. In this study, the frequency given to PMM Strut Fin is 1-100 $\mathrm{Hz}$. Harmonic response analysis used in this study was analyzed under no load conditions. The no-load condition is defined as the condition when the Strut Fin PMM attaches to the Towing Tank carriage without the load of the ship model below it. To assist the calculation of harmonic response using FEM software [10-13].

\section{Results Analysis and Discussion}

Deformation occurs due to natural frequencies that affect the structure of the Strut Fin PMM. By using FEM software, the maximum value and minimum deformation values that occur in the PMM Strut Fin are obtained. The natural frequency that occurs is shown in Table 3.

Table 3. Mode vs Frequency vs Displacement

\begin{tabular}{ccc}
\hline Mode & Natural Frequency $(\mathbf{H z})$ & Max. Displ. $(\mathbf{m})$ \\
\hline 1 & 0.0371 & 0.0532 \\
\hline 2 & 433.339 & 0.1148 \\
\hline 3 & 502.121 & 0.0899 \\
\hline 4 & 776.368 & 0.0353 \\
\hline 5 & 867.883 & 0.0469 \\
\hline
\end{tabular}

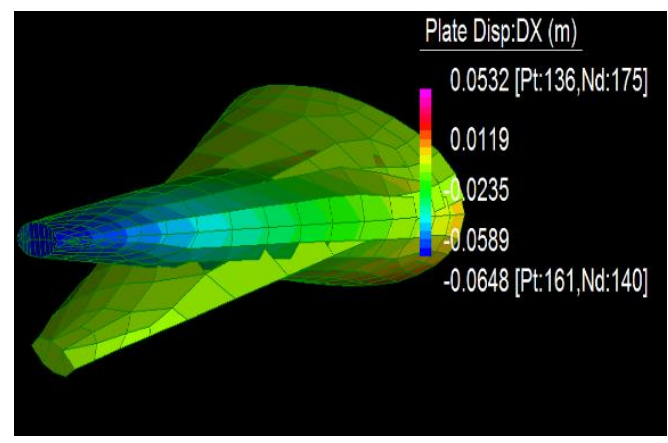

Figure 3. First Mode

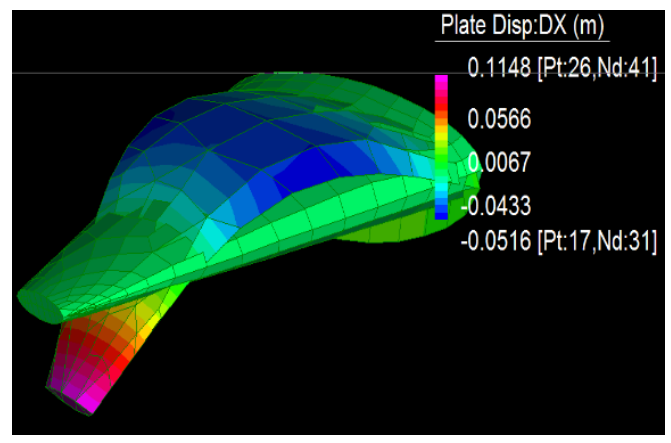

Figure 4. Second Mode
Table 4. Frequency vs Displacement vs Pressure

\begin{tabular}{|c|c|c|c|c|c|}
\hline $\begin{array}{c}\text { Freq. } \\
(\mathrm{Hz})\end{array}$ & $\begin{array}{l}\text { Displ. } \\
(\mathrm{mm})\end{array}$ & $\begin{array}{c}\text { Pressure } \\
(\mathrm{Pa})\end{array}$ & $\begin{array}{c}\text { Freq. } \\
(\mathrm{Hz})\end{array}$ & $\begin{array}{l}\text { Displ. } \\
(\mathbf{m m})\end{array}$ & $\begin{array}{c}\text { Pressure } \\
(\mathbf{P a})\end{array}$ \\
\hline 1 & $2.50 \mathrm{E}-12$ & $2.95 \mathrm{E}-05$ & 51 & $6.64 \mathrm{E}-16$ & $1.38 \mathrm{E}-05$ \\
\hline 2 & $6.24 \mathrm{E}-13$ & $1.69 \mathrm{E}-05$ & 52 & $6.28 \mathrm{E}-16$ & $1.38 \mathrm{E}-05$ \\
\hline 3 & $2.77 \mathrm{E}-13$ & $1.51 \mathrm{E}-05$ & 53 & $5.93 \mathrm{E}-16$ & $1.38 \mathrm{E}-05$ \\
\hline 4 & $1.56 \mathrm{E}-13$ & $1.45 \mathrm{E}-05$ & 54 & $5.61 \mathrm{E}-16$ & $1.38 \mathrm{E}-05$ \\
\hline 5 & $9.95 \mathrm{E}-14$ & $1.42 \mathrm{E}-05$ & 55 & $5.30 \mathrm{E}-16$ & $1.38 \mathrm{E}-05$ \\
\hline 6 & $6.90 \mathrm{E}-14$ & $1.41 \mathrm{E}-05$ & 56 & $5.01 \mathrm{E}-16$ & $1.38 \mathrm{E}-05$ \\
\hline 7 & $5.06 \mathrm{E}-14$ & $1.40 \mathrm{E}-05$ & 57 & $4.73 \mathrm{E}-16$ & $1.38 \mathrm{E}-05$ \\
\hline 8 & $3.87 \mathrm{E}-14$ & $1.39 \mathrm{E}-05$ & 58 & $4.47 \mathrm{E}-16$ & $1.38 \mathrm{E}-05$ \\
\hline 9 & $3.05 \mathrm{E}-14$ & $1.39 \mathrm{E}-05$ & 59 & $4.22 \mathrm{E}-16$ & $1.38 \mathrm{E}-05$ \\
\hline 10 & $2.47 \mathrm{E}-14$ & $1.38 \mathrm{E}-05$ & 60 & $3.98 \mathrm{E}-16$ & $1.38 \mathrm{E}-05$ \\
\hline 11 & $2.03 \mathrm{E}-14$ & $1.38 \mathrm{E}-05$ & 61 & $3.75 \mathrm{E}-16$ & $1.38 \mathrm{E}-05$ \\
\hline 12 & $1.70 \mathrm{E}-14$ & $1.38 \mathrm{E}-05$ & 62 & $3.54 \mathrm{E}-16$ & $1.38 \mathrm{E}-05$ \\
\hline 13 & $1.45 \mathrm{E}-14$ & $1.38 \mathrm{E}-05$ & 63 & $3.34 \mathrm{E}-16$ & $1.38 \mathrm{E}-05$ \\
\hline 14 & $1.24 \mathrm{E}-14$ & $1.38 \mathrm{E}-05$ & 64 & $3.14 \mathrm{E}-16$ & $1.38 \mathrm{E}-05$ \\
\hline 15 & $1.08 \mathrm{E}-14$ & $1.38 \mathrm{E}-05$ & 65 & $2.96 \mathrm{E}-16$ & $1.38 \mathrm{E}-05$ \\
\hline 16 & $9.45 \mathrm{E}-15$ & $1.38 \mathrm{E}-05$ & 66 & $2.78 \mathrm{E}-16$ & $1.38 \mathrm{E}-05$ \\
\hline 17 & 8.34E-15 & $1.38 \mathrm{E}-05$ & 67 & $2.61 \mathrm{E}-16$ & $1.38 \mathrm{E}-05$ \\
\hline 18 & $7.41 \mathrm{E}-15$ & $1.37 \mathrm{E}-05$ & 68 & $2.45 \mathrm{E}-16$ & $1.38 \mathrm{E}-05$ \\
\hline 19 & $6.62 \mathrm{E}-15$ & $1.37 \mathrm{E}-05$ & 69 & $2.29 \mathrm{E}-16$ & $1.38 \mathrm{E}-05$ \\
\hline 20 & 5.94E-15 & $1.37 \mathrm{E}-05$ & 70 & $2.14 \mathrm{E}-16$ & $1.38 \mathrm{E}-05$ \\
\hline 21 & $5.36 \mathrm{E}-15$ & $1.37 \mathrm{E}-05$ & 71 & $2.00 \mathrm{E}-16$ & $1.38 \mathrm{E}-05$ \\
\hline 22 & $4.86 \mathrm{E}-15$ & $1.37 \mathrm{E}-05$ & 72 & $1.86 \mathrm{E}-16$ & $1.38 \mathrm{E}-05$ \\
\hline 23 & 4.42E-15 & $1.37 \mathrm{E}-05$ & 73 & $1.73 \mathrm{E}-16$ & $1.38 \mathrm{E}-05$ \\
\hline 24 & $4.04 \mathrm{E}-15$ & $1.37 \mathrm{E}-05$ & 74 & $1.61 \mathrm{E}-16$ & $1.38 \mathrm{E}-05$ \\
\hline 25 & $3.70 \mathrm{E}-15$ & $1.37 \mathrm{E}-05$ & 75 & $1.49 \mathrm{E}-16$ & $1.39 \mathrm{E}-05$ \\
\hline 26 & $3.40 \mathrm{E}-15$ & $1.37 \mathrm{E}-05$ & 76 & $1.37 \mathrm{E}-16$ & $1.39 \mathrm{E}-05$ \\
\hline 27 & $3.13 \mathrm{E}-15$ & $1.37 \mathrm{E}-05$ & 77 & $1.26 \mathrm{E}-16$ & $1.39 \mathrm{E}-05$ \\
\hline 28 & $2.89 \mathrm{E}-15$ & $1.37 \mathrm{E}-05$ & 78 & $1.15 \mathrm{E}-16$ & $1.39 \mathrm{E}-05$ \\
\hline 29 & $2.67 \mathrm{E}-15$ & $1.37 \mathrm{E}-05$ & 79 & $1.05 \mathrm{E}-16$ & $1.39 \mathrm{E}-05$ \\
\hline 30 & $2.48 \mathrm{E}-15$ & $1.37 \mathrm{E}-05$ & 80 & $9.49 \mathrm{E}-17$ & $1.39 \mathrm{E}-05$ \\
\hline 31 & $2.30 \mathrm{E}-15$ & $1.37 \mathrm{E}-05$ & 81 & $8.54 \mathrm{E}-17$ & $1.39 \mathrm{E}-05$ \\
\hline 32 & $2.14 \mathrm{E}-15$ & $1.37 \mathrm{E}-05$ & 82 & 7.62E-17 & $1.39 \mathrm{E}-05$ \\
\hline 33 & $2.00 \mathrm{E}-15$ & $1.37 \mathrm{E}-05$ & 83 & $6.73 \mathrm{E}-17$ & $1.39 \mathrm{E}-05$ \\
\hline 34 & $1.86 \mathrm{E}-15$ & $1.37 \mathrm{E}-05$ & 84 & $5.87 \mathrm{E}-17$ & $1.39 \mathrm{E}-05$ \\
\hline 35 & $1.74 \mathrm{E}-15$ & $1.37 \mathrm{E}-05$ & 85 & $5.05 \mathrm{E}-17$ & $1.39 \mathrm{E}-05$ \\
\hline 36 & $1.63 \mathrm{E}-15$ & $1.37 \mathrm{E}-05$ & 86 & $4.25 \mathrm{E}-17$ & $1.39 \mathrm{E}-05$ \\
\hline 37 & $1.53 \mathrm{E}-15$ & $1.37 \mathrm{E}-05$ & 87 & $3.48 \mathrm{E}-17$ & $1.39 \mathrm{E}-05$ \\
\hline 38 & $1.43 \mathrm{E}-15$ & $1.37 \mathrm{E}-05$ & 88 & $2.74 \mathrm{E}-17$ & $1.39 \mathrm{E}-05$ \\
\hline 39 & $1.35 \mathrm{E}-15$ & $1.38 \mathrm{E}-05$ & 89 & $2.02 \mathrm{E}-17$ & $1.39 \mathrm{E}-05$ \\
\hline 40 & $1.26 \mathrm{E}-15$ & $1.38 \mathrm{E}-05$ & 90 & $1.32 \mathrm{E}-17$ & $1.39 \mathrm{E}-05$ \\
\hline 41 & $1.19 \mathrm{E}-15$ & $1.38 \mathrm{E}-05$ & 91 & $6.51 \mathrm{E}-18$ & $1.39 \mathrm{E}-05$ \\
\hline 42 & $1.12 \mathrm{E}-15$ & $1.38 \mathrm{E}-05$ & 92 & $1.11 \mathrm{E}-20$ & $1.39 \mathrm{E}-05$ \\
\hline 43 & $1.05 \mathrm{E}-15$ & $1.38 \mathrm{E}-05$ & 93 & $6.28 \mathrm{E}-18$ & $1.39 \mathrm{E}-05$ \\
\hline 44 & $9.94 \mathrm{E}-16$ & $1.38 \mathrm{E}-05$ & 94 & $1.24 \mathrm{E}-17$ & $1.39 \mathrm{E}-05$ \\
\hline 45 & $9.37 \mathrm{E}-16$ & $1.38 \mathrm{E}-05$ & 95 & $1.83 \mathrm{E}-17$ & $1.39 \mathrm{E}-05$ \\
\hline 46 & $8.84 \mathrm{E}-16$ & $1.38 \mathrm{E}-05$ & 96 & $2.40 \mathrm{E}-17$ & $1.39 \mathrm{E}-05$ \\
\hline 47 & $8.34 \mathrm{E}-16$ & $1.38 \mathrm{E}-05$ & 97 & $2.95 \mathrm{E}-17$ & $1.40 \mathrm{E}-05$ \\
\hline 48 & $7.88 \mathrm{E}-16$ & $1.38 \mathrm{E}-05$ & 98 & $3.49 \mathrm{E}-17$ & $1.40 \mathrm{E}-05$ \\
\hline 49 & 7.44E-16 & $1.38 \mathrm{E}-05$ & 99 & $4.01 \mathrm{E}-17$ & $1.40 \mathrm{E}-05$ \\
\hline 50 & 7.03E-16 & $1.38 \mathrm{E}-05$ & 100 & $2.84 \mathrm{E}-14$ & $8.78 \mathrm{E}-03$ \\
\hline
\end{tabular}




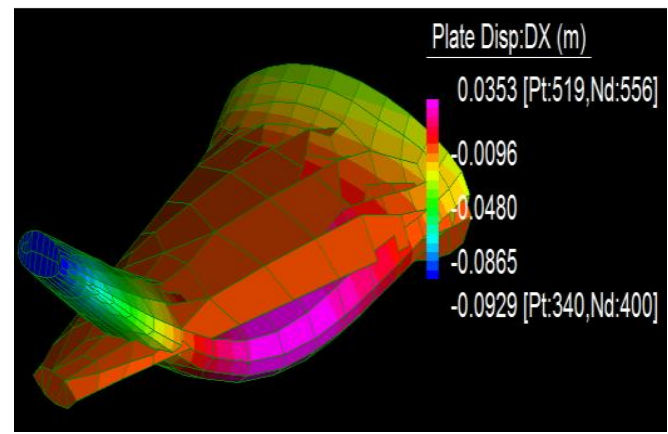

Figure 5. Third Mode

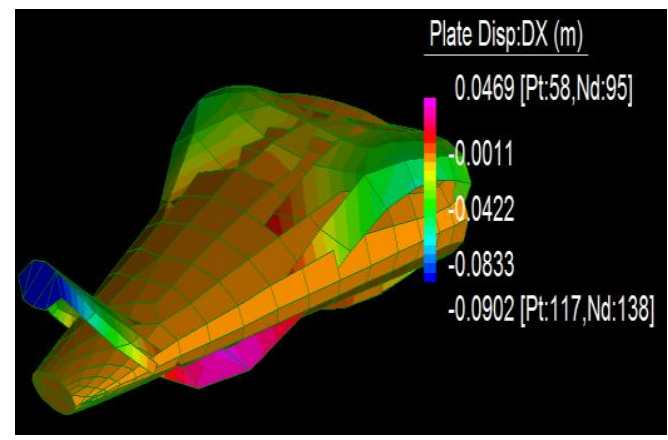

Figure 6. Fourth Mode

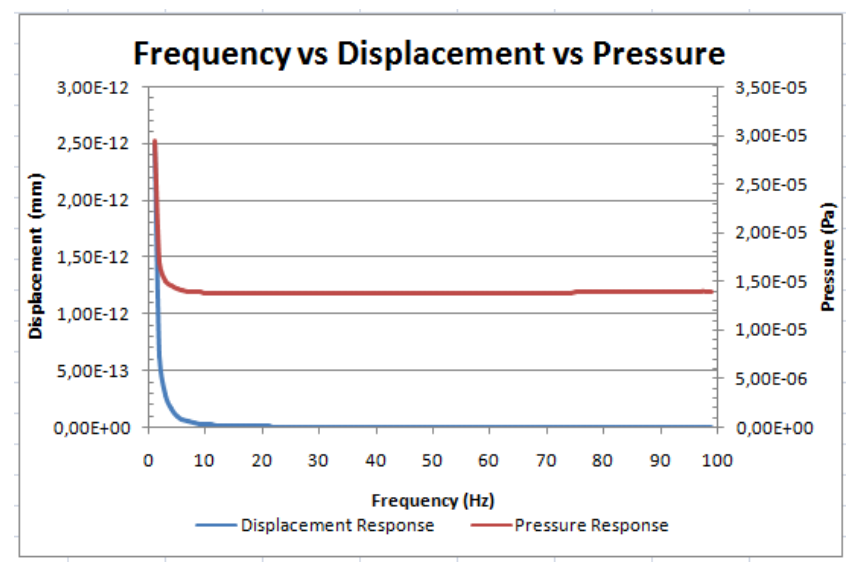

Figure 7. Frequency vs Displacement vs Pressure

After knowing the natural frequency value, the value is used to input the harmonic response analysis, where the harmonic response of the spectrum value is 1 to 100 $\mathrm{Hz}$, the results from the three spectra are shown in Table 4.

Figure 7 shows that at a frequency of $1 \mathrm{~Hz}$ Strut Fin PMM displacement of $2.50 \mathrm{E}-12 \mathrm{~mm}$, the displacement value the higher the frequency decreases in the sense that the resonance structure of the Strut Fin PMM at very high frequencies is very small. While for stress at a frequency of $1 \mathrm{~Hz}$ is $2.95 \mathrm{E}-05 \mathrm{~Pa}$. The value of stress the higher the frequency decreases to a frequency of $18 \mathrm{~Hz}-$ $38 \mathrm{~Hz}$ with a value of $1.37 \mathrm{E}-05 \mathrm{~Pa}$, after that the value of pressure increases again but the value is small at $100 \mathrm{~Hz}$.

\section{Conclusion}

In a structure, one of the factors that cause failure is the resonance of the structure. By knowing the resonance value, in this case, the natural frequency of Strut Fin PMM, it can avoid natural frequencies which can endanger the structure. In the Strut Fin PMM structure with variations in frequency between $1-100 \mathrm{~Hz}$ the displacement value that occurs is still within normal limits. Largest displacement value occurs at a high frequency of $1 \mathrm{~Hz}$ and the lowest displacement value at a frequency of $100 \mathrm{~Hz}$. For the highest stress value at a frequency of $1 \mathrm{~Hz}$. In the frequency range that has been studied, it becomes a reference when designing the motor needs for Strut Fin PMM drive, so that when testing the motor frequency is in the range of $0-100 \mathrm{~Hz}$, thus the deformation that occurs is still within normal limits

\section{Acknowledgments}

The authors highly appreciates to Center of Technology for Maritime Industrial Engineering BPPT who have allowed using software FEM Strand 7.

\section{References}

[1] M. Gertler, "The DTMB Planar Motion Mechanism System," no. July 1967, 1967.

[2] S. U. Sawant, S. J. Chauhan, and N. N. Deshmukh, "Effect of crack on natural frequency for beam type of structures," AIP Conf. Proc., vol. 1859 , pp. 1-7, 2017

[3] A. V Deokar and V. D. Wakchaure, "Experimental Investigation of Crack Detection in Cantilever Beam Using Natural Frequency as Basic Criterion," Int. Conf. Curr. Trends Technol., pp. 8-10, 2011.

[4] A. S. Kumar, "Modeling and Analysis of a Composite Wing for Missile Structure," vol. 8, no. 6, pp. 338-347, 2017.

[5] G. R. Gillich, P. F. Minda, Z. I. Praisach, and A. A. Minda, "Natural Frequencies of Damaged Beams - A New Approach," Rom. J. Acoust. Vib., vol. 9, no. 2, pp. 101-108, 2012.

[6] N. Mubarok, H. A. Notonegoro, K. A. Z. Thosin, and A. Manaf, "The Effect of Mechanical Deformation to The Magnetic Properties of Stainless Steel 304," J. Phys. Conf. Ser., vol. 776, no. 1, pp. 8-11, 2016.

[7] G.-Y. Kim, M. Koç, and J. Ni, "Experimental and Numerical Investigations on Microcoining of Stainless Steel 304," J. Manuf. Sci. Eng., vol. 130, no. 4, p. 41017, 2008.

[8] N. Mubarok, H. A. Notonegoro, and K. A. Z. Thosin, "Comparative Mechanical Improvement of Stainless Steel 304 Through Three Methods," IOP Conf. Ser. Mater. Sci. Eng., vol. 367, no. 1, pp. 1-6, 2018.

[9] M. Shukla, P. Agarwal, M. K. Pradhan, and S. K. Dhakad, "Experimental Investigation of EDM Parameters on AlLM6/SiC/B4C Hybrid Composites," Appl. Mech. Mater., vol. 877, no. 8, pp. 149-156, 2018.

[10]H. J. Hu, "Simulations of Isothermal ECAE for Magnesium Alloy using FEM Software and Experimental Validations," J. Manuf. Process., vol. 14, no. 3, pp. 181-187, 2012.

[11]G. Liu, C. Huang, R. Su, T. Özel, Y. Liu, and L. Xu, “3D FEM Simulation of The Turning Process of Stainless Steel 17-4PH with Differently Texturized Cutting Tools," Int. J. Mech. Sci., vol. 155, no. November 2018, pp. 417-429, 2019.

[12] J. Klon, J. Sobek, and V. Veselý, "Spatial Modeling of WedgeSplitting Test on Cylindrical Specimens Using FEM Software," Procedia Eng., vol. 190, pp. 427-432, 2017.

[13] G. Ortiz-De-Zarate et al., "Experimental and FEM Analysis of Surface Integrity when Broaching Ti64," Procedia CIRP, vol. 71, pp. 466-471, 2018. 